日植病報 $33: 138 \sim 143$ (1967)

Ann. Phytopath. Soc. Japan. 33: 138 143 (1967)

\title{
イネ葉上括よび組織内に特けるフェニルヒドラジンアシル 誘導体のいもち病菌に対する作用*
}

\author{
角, 名 郁 郎**. 松 浦 一 穂** \\ Ikuo Sumina** and Kazuho Matsuura**: Effect of $\beta$-acylphenylhydrazine \\ Derivatives on Blast Fungus upon Leaves and in \\ Tissues of Rice Plant*
}

\begin{abstract}
Studies were carried out with the efficacy of 1-(3, 4-dichlorophenyl)-2- acetylhydrazine (I) and 1-(4-chloropheny1)-2- acetylhydrazine (II), which showed the strongest and the most consistent effect on rice blast control among $\beta$-acylchlorophenylhydrazine derivatives, in suppressing developing mycelia and germination of spores of Pyricularia oryzae in vitro, on leaves and in tissues of rice plant.

Compounds I and II were found to possess complete sporostatic property at $125 \mathrm{ppm}$ on the slide glass, and both I and II at $175 \mathrm{ppm}$ and above prevented the mycelial growth in shaking culture. While mycocidal action of these compounds were stronger than sporocidal action.

On the leaves of rice plant, both I and II at $1000 \mathrm{ppm}$ did not prevent sufficiently spore germination and appressorium formation, but suppressed markedly the mycelial development in the host tissues as well as blasticidin S, a therapeutic agent.

These results suggested that the principal locus of inhibition of $\beta$-acylchlorophenylhydrazines against rice blast fungus in the protective and the therapeutic tests was at the stage of mycelial development in the tissues, and not at the stage of spore germination and appressorium formation upon leaves of rice plant.
\end{abstract}

(Received July 18, 1966)

前報 ${ }^{3)}$ で $\beta$ アシルクロロフェニルヒドラジン誘導 体がイネいもち病に対して強い防除効果を示すことを 報告した。その防除作用の特徵はいもち病に予防なら びに治療効果を有する点にあり，また病斑は褐点型で 止る場合が多く認められた。

本報では代表化合物として，1-(3，4-dichlorophenyl)-2-acetylhydrazine 特よび 1-(4-chlorophenyl)2-acetylhydrazine を選び，それらの in vitro なら

* 農業用殺菌剂に関する研究 第 9 報 Studies on agricultural fungicides. IX.

** 武田薬品研究開発本部京都試験農園 Kyoto Herbal Garden, Research and Development Division, Takeda Chemical Industries, Ltd.
びにイネ葉上，組織内におけるいるら病菌に対する作 用を検討したところ, 既存の抗いもち病剂と作用を異 にする点があることが分ったのでここに報告する。 本研究を行ならにあたり, 終始御鞭撻を賜わった当 社顧問田中一郎博士, 農園長八田亮三氏, 主任研究員 小林忠之博士，また供試化合物の合成を担当され，種 々有益なる御助言, 御指導を頂いた農薬技術部主任研 究員衣川二郎博士ならびに碓井義郎研究員に深謝する。 また本稿を草するにあたり御校閲を賜わった京大教授 赤井重恭博士に対し感謝の意を表する。

\section{実験材料および方法}

1. 分生胞子発芽試験 いもち病菌 Pyricularia 
oryzae（p-18）はイネわら煎汁液体培地を用いて，ス ポンジマトリックス法”により, $28^{\circ} \mathrm{C}$ で 4 日間振盪 培養し, その後菌糸の十分生育したスポンジマトリッ クスをとり出し, 水洗後湿室 $\left(28^{\circ} \mathrm{C}\right)$ に 24 時間保ち 同調胞子を形成させる。こうして得られた同調胞子を 洗浄後, $0.3 \mathrm{M}$ の庶糖を含む $1 / 15 \mathrm{M}$ リン酸 緩 衝 液 (pH 6.4) に再懸濁乙試験胞子液（胞子濃度約 $5 \times 10^{5}$ \% $\mathrm{m} l$ ) とした。発芽試験は試験管希釈法に準拠した。 な拉 1 処理に約 300 個の胞子数を調べ, 無処理に対す る比率から阻害率を算出した。

2. 菌系生育阻害試験 $300 \mathrm{ml}$ 容の振盪コル゚ベン 飞 $50 \mathrm{ml}$ のイネわら煎汁液体培地を入れ, 隇菌後 $2 \mathrm{~m} l$ の胞子浮遊液（胞子濃度約 $5 \times 10^{5} / \mathrm{m} l$ ) を接種 し， $28^{\circ} \mathrm{C}$ で振盪培養した。 24 または 48 時間後所定 の濃度になるように薬液を添加し，さらに 3 日または 2 日間 (接種後 4 日間) 培養した。その後菌糸を水洗, 乾燥し, 薬阂無添加区との重量比により阻害率を算出 した。なお 1 処理 2 コルベンを使用し反復試験し た。

3. 菌系, 分生胞子および分生胞子形成に対する殺 菌試験 sporocidal, mycocidal な作用は柳田ら 51 の 万法を用いて試験した。すなわち，胞子，菌系片とも に遠心分離による時間も含めて正確に 20 分薬液と接 触させた後水洗し，1ペトリ血市たり 200〜300 個の コロニー数になるような濃度（菌系の場合はワーリ ングブレンダーで細片にする。分生胞子の場合は胞子 数約 $8 \times 10^{3}$ 個) に調整し,イネわら寒天培地を流した ペトリ皿に移し, $28^{\circ} \mathrm{C}$ で 24 時間培屋した。菌の生死 の判別は無処理に対するコロニ一数から行ない, その 比率から阻害率を算出した。な和 1 処理 2 ペトリ皿で 反復試験した。

分生胞子形成に対する試験は，スポンジマトリック ス法1)により，スポンジマトリックス（1 処理 10 個） に生育した子梗形成前の菌糸を正確に 20 分間薬液と 接触させ, 水洗後湿室 $\left(28^{\circ} \mathrm{C}\right)$ に保ち, 24 時間後に 形成された胞子数を無処理の胞子数と比較し阻害率を 求めた。

4. イネ葉上の分生胞子発芽および葉鞘 組 織 内 菌 糸に対する限害試験 温室内ポットおよびベッド試 験 ${ }^{3)}$ に抹いて, 薬蝺散布 2 日後に接種した場合のイネ 葉上の分生胞子発芽の状態をつぎの方法で調べた。す なわち接種後約 16 または 18 時間経過後, 葉を 4 ～ $5 \mathrm{~cm}$

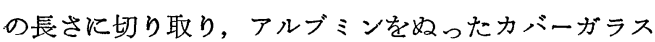
にこれを貼りつけ固定し2，カバーガラスに付着した 胞子を 1 処理あたり約 100 個検鏡する（1 処理 5〜6
葉, ベッド試験の場合）かあるいは以下に記す手順に より固定, 染色し観察した（ポット試験の場合）。ま ず上記イネ葉をカルノアの固定液（6:3:1）で固定 し, $95 \%, 75 \%$ タノール杖よび水までのアルコール シリーズを通す。水洗後アニリンブルー染色液で 5 分 間染色する ${ }^{4)}$ 。その後スライド上に打いて $5 \%$ 乳酸液 中で $2 \sim 3$ 分間加温し，水洗後検鏡し 1 処理あたり約 60 個の胞子数（5～6 葉）を調査した。阻害率は無処 理に対する比率から求めた。

組織内の菌糸に対する作用は葉鞘接種法により観察 した。すなわら常法によりいもち病菌胞子浮遊液（胞 子濃度約 $\left.5 \times 10^{5} / \mathrm{ml}\right)$ を葉鞘内に接種し, 湿室 $\left(28^{\circ} \mathrm{C}\right)$ に 24 時間保ち, その後薬液に 10 分間浸漬処理した。 さらに 24 ならびに 48 時間湿室に保った後, 葉鞘内壁 をはがし，前記の手順により固定，染色し，顕微鏡 （600 倍）下で観察した。1 処理あたり 5〜6葉䩗を供 試し, 約 30 の侵入菌杀による感染の状態を細胞数か ら調べた。

5. 供試薬剤 1-(3,4-dichlorophenyl)-2-acetylhydrazine (I), 1-(4-chlorophenyl)-2-acetylhydrazine (II), phenylmercuric acetate (PMA), Blasticidin $\mathrm{S} \cdot \mathrm{HCl}(\mathrm{BcS})$, phenylmercuric iodide (PMI) の 5 薬阂を使用した。I，II は結晶をエタノールに溶かし 水で希釈し，その他はそのまま水に溶解し用いた。PM Aならびに PMI は水銀濃度に換算して用いた。な拉 イネを用いた各試験では展着剤を $0.02 \%$ 割合に加 え使用した。

\section{実験結果および考察}

\section{1. 分生胞子発芽阻害作用}

各薬剤は倍数希釈により 7 段階の濃度を設け試験し た。結果は第1図に示したが，無処理区に特ける発芽 率は平均 90\%であった。I および II はともに 125 ppm の濃度で胞子発芽を完全に抑制したが，その作 用はIにくらべて II の方が強く, $62.5 \mathrm{ppm}$ でI の 阻害率が $12 \%$ に対し, II は 86\%であった。一方 PMA は $0.13 \mathrm{ppm}, \mathrm{BcS}$ は $0.4 \mathrm{ppm}$ の濃度で胞子発芽を 完全に抑制し, 実用濃度の $1 / 20$ 以下で強い作用が認 められた。

\section{2. 菌系生育阳害作用}

菌糸生育の誘導期（接種 24 時間後, 図左）または 対数初期（接種 48 時間後, 四右）に所定の濃度にな るように薬液を添加し, 菌糸の生育に与える影響をみ た結果が第 2 図である。接種 24 時間後の薬剤添加で は, I は $350 \mathrm{ppm}$ で完全阻害, $175 \mathrm{ppm}$ 以上で高い 


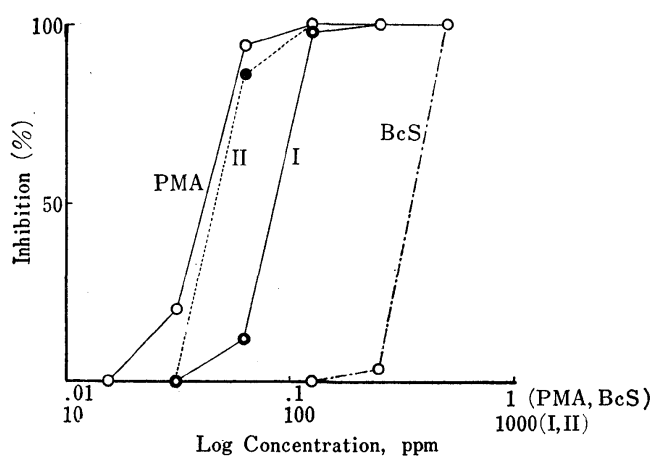

Fig. 1 Effect of $\beta$-acetylchlorophenylhydrazines, phenylmercuric acetate and blasticidin $\mathrm{S}$ on spore germination of Pyricularia oryzae.

I : 1-(3,4-dichlorophenyl) -2-acetylhydrazine

II : 1-(4-chlorophenyl)-2-acetylhydrazine

PMA : phenylmercuric acetate

$\mathrm{BcS}$ : blasticidin $\mathrm{S}$

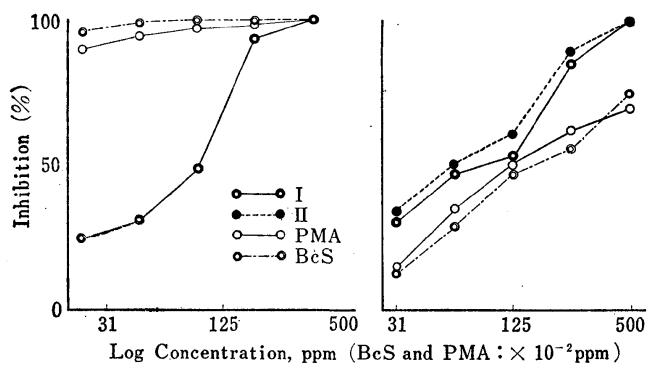

Fig. 2 Inhibitory effect of $\beta$-acetylchlorophenylhydrazines, PMA and $\mathrm{BcS}$ on the mycelial development of $P$. oryzae. Chemicals were added 24 (left) or 48 (right) hours after inoculation.

阻害を示した。 $87 \mathrm{ppm}$ ではかなり作用が低下し， $50 \%$ 程度の阻害を示すに過ぎなかった。 $\mathrm{BcS}$, PMA はともに菌系生育に対する作用は著しく強く, 供試濃 度範囲ではほぼ完全に阻害した。一方接種 48 時間後 の薬剤添加では, $\mathrm{BcS}$ および PMA の阻害作用には 誘導期添加とくらべて著しい低下が認められたが，化 合物 I の場合は誘導期添加とほぼ同じ程度の阻害作 用を示した。また化合物 II には I とほとんど同程度 の菌糸生育阻害作用が認められた。

以上の実験結果から，化合物 I 和よび II はとも に菌䒺生育阻害作用より胞子発芽に対する阻害作用が やや強いようであり, ともにより低濃度で完全阻害が 認められた。しかし以上の 2 種類の試験は方法も異な

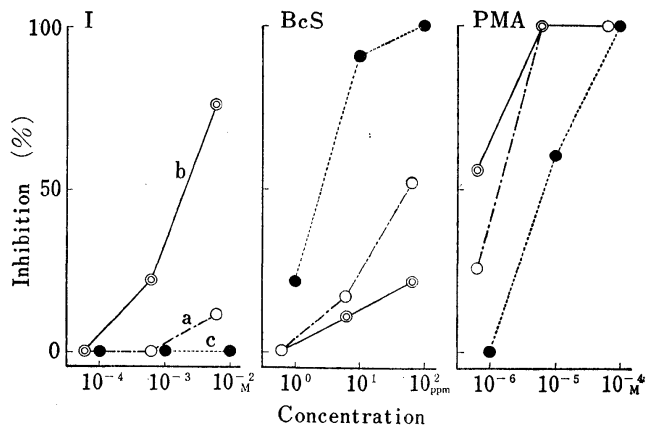

Fig. 3 Comparison of sporocidal (a), mycocidal (b) and sporulation inhibitory (c) activities of $1 \cdot(3,4$-dichlorophenyl)-2-acetylhydrazine, $\mathrm{BcS}$ and $\mathrm{PMA}$ on $P$. oryzae.
-O--.-O- Sporocidal
-(O)——- Mycocidal
Sporulation inhibition

るため，その結果から菌系および胞子のどちらに対す る作用が強いかは論じられないと思われ，つぎの実験: を行なった。

3. 分生胞子，菌系ならびに胞子形成における薬剤 感受性 いもち病菌分生胞子, 菌䒺拈よび分生胞子形 成前の菌糸（スポンジマトリックス中菌糸）などを 薬剤と 20 分間接触させ, どのステージに最も強く薬. 剤が反応するかを実験した。第 3 図がその結果である が，I はかなり特異的な作用を示した。すなわちこの. 化合物は分生胞子発芽および胞子形成に対する阻害作 用は弱いが，菌系生育に対する阻害が強かった。BcS， は胞子形成阻害作用が強いのにくらべ, 胞子発芽, 菌 糸生育阻害作用はやや低く，また PMA は胞子発芽: および菌糸生育阻害作用が強く, 胞子形成に対する阻. 害作用はやや低かった。

以上の結果のように分生胞子, 菌系拉よび分生胞子 形成などに対して，各薬剤はそれぞれ三様の相違する 薬剤感受性を示した。化合物 I はい子ち病菌分生胞: 子小よび胞子形成に対するよりも菌系に対して阻害が. 強いことが特徵であると考えられる。

\section{4. イネ葉上の分生胞子発芽および葉鞘組織内の菌} 糸に対する阻害作用 まずイネ葉上の胞子発芽に対す る阻害を観察した（第 $1 ， 2$ 表）。薬剤はおの㧍の接: 種 2 日前に散布した。第 1 表はポット試験による結果 で，接種約 18 時間後の状態を調べた。無散布におけ る胞子発芽率は $91 \%$ であった。化合物 I では発芽阻害 がやや認められる程度であったが，II の阻害作用はほ とんどなかった。一方 PMI は 20 ppm で発芽をほ: 
Table 1. Inhibitory effect of $\beta$-acetylchlorophenylhydrazines on spore germination and appressorium formation upon rice leaves in the pot test ${ }^{a)}$ in greenhouse.

\begin{tabular}{c|l|c|c|c|c}
\hline \hline $\begin{array}{l}\text { Code } \\
\text { no. }\end{array}$ & \multicolumn{1}{|c|}{ Chemicals } & $\begin{array}{l}\text { Concentration } \\
\text { (ppm) }\end{array}$ & $\begin{array}{l}\text { Inhibition of } \\
\text { spore germination }\end{array}$ & $\begin{array}{l}\text { Inhibition of } \\
\text { appressorium } \\
\text { formation }\end{array}$ & $\begin{array}{l}\text { Percent disease } \\
\text { control }\end{array}$ \\
\hline I & $\begin{array}{l}\text { l-(3,4-dichloro } \\
\text { phenyl)-2-acetyl- } \\
\text { hydrazine }\end{array}$ & 1000 & $20 \%$ & 56 \\
$\begin{array}{l}\text { 1-(4-chloro- } \\
\text { phenyl)-2-acetyl } \\
\text { hydrazine } \\
\text { PMA }\end{array}$ & 1000 & 3 & 6 & 80 \\
Blasticidin S & $20^{b)}$ & 100 & - & 98 \\
Check & 20 & 6 & $0^{\text {c) }}$ & 69 \\
\hline
\end{tabular}

a) Chemicals were sprayed 2 days before inoculation.

b) Concentration as mercury.

c) Spore germination percentage: $91 \%$

d) Percent of appressorium formation: $74 \%$

Table 2. Inhibitory effect of 1-(3,4-dichlorophenyl)-2-acetylhydrazine on spore germination upan rice leaves in the seedling bed test ${ }^{a}$ ) in greenhouse

\begin{tabular}{|c|c|c|c|c|}
\hline \multirow{2}{*}{ Chemicals } & \multirow{2}{*}{$\begin{array}{l}\text { Concen- } \\
\text { tration } \\
\text { (ppm) }\end{array}$} & \multirow{2}{*}{$\begin{array}{l}\text { Percent } \\
\text { inhibition } \\
\text { of spore } \\
\text { germina- } \\
\text { tion }\end{array}$} & \multicolumn{2}{|c|}{$\begin{array}{l}\text { Percent disease } \\
\text { control }\end{array}$} \\
\hline & & & $6^{b)}$ & 9 \\
\hline $\begin{array}{l}\text { 1-(3,4-di- } \\
\text { chlorophenyl)- } \\
2 \text {-acetyl- } \\
\text { hydrazine }\end{array}$ & 1000 & 64 & 95 & 90.1 \\
\hline $\mathrm{PMI}^{(\mathrm{l})}$ & 20 & 97 & 100 & 98.6 \\
\hline Blasticidin S & 20 & 72 & 95 & 88.7 \\
\hline Check & - & $0^{d)}$ & $0^{e)}$ & $0^{f)}$ \\
\hline
\end{tabular}

a) Chemicals were sprayed 2 days before inoculation.

b) Days elapsed after inoculation.

e) Phenylmercuric iodide, concentration as mercury.

d) Spore germination percentage: $78 \%$

e) Percent area of spots: $57 \%$

f) " " " : $71 \%$

㳘完に阻害したが， BcS は 20 p pm でも発芽阻害 をほとんど示さなかった。また付着器形成に対する阻 害作用をみると，II 拈よび BcS 処理では無処理とほ とんど同じくらい付着器を形成するのに対し，I の処 理ではその形成がやや抑制されるようであった。なお 無散布の付着器形成率は $74 \%$ この試験で同一処理 した他のポットで発病程度を調査したが，胞子の発芽 を強く抑制した PMA 処理区は病斑をほとんど形成
しなかった。化合物I も発芽阻害率が PMA に比しか なり低いにもかかわらず，防除効果はほぼ同等であっ た。化合物 II を処理したイネではIにくらべて発病 が多かったが， BcS の効果に優っていた。つぎに第 2 表のベッド試験に拉ける結果であるが，第 1 表の結 果とほぼ同様の知見を得た。すなわち調査は接種後約 16 時間目に行なったが, 化合物 I の発芽阻害率は $\mathrm{BcS}$ よりもやや低かった。な拈無散布の発芽率は78\% であった。しかし防除効果は数字にはっきりと現われ る程ではないが，傾向的に BcS の効果よりやや優っ ていた。一方 PMI は発芽阻害効果が高く, 発病をほ とんど完全に抑制した。発芽阻害率がポット試験の場 合とやや違うのは試験方法拈よび調查方法の違いが関 係していると思う。

以上の結果から考觉て, $\beta$-アシルクロロフェニルヒ ドラジン誘導体のイネ葉上でのいもち菌に対する阻害 作用は胞子発芽，付着器形成のいずれにも弱い。しか し防除効果が高く現われるといら事実から, 葉内の侵 入菌糸に対して強い阻害作用を示すことが予測され る。

つぎに葉鞘接種法によって,イネ幼苗葉䩗組織内の 菌系に対する作用につき実験した（第 4 図，第 3 表）。 その結果化合物 I 特よび II はともに組織内菌糸の 伸長を強く阻害し, $\mathrm{BcS}$ とほぼ同等の作用が認められ た。 BcS は予防効果は高くないが, 治療効果が著しく, その阻害は組織内の菌糸に対して強い。第 3 表には組 織内菌糸の伸長阻害について, 1 侵入菌糸から侵害を 受けた細胞数の経時的変化を調べて示した。化合物 I および II は接種後 48 時間（薬剂処理後 24 時間）の 
Table 3. Inhibitory effect of $\beta$-acetylchlorophenylhydrazines, $\mathrm{PMI}$ and $\mathrm{BcS}$ on the mycelial development in leaf sheath tissues of rice seedlings.

\begin{tabular}{|c|c|c|c|c|c|}
\hline \multirow{2}{*}{ Code no. } & \multirow{2}{*}{ Chemicals } & \multirow{2}{*}{$\begin{array}{r}\text { Concentration } \\
(\mathrm{ppm})\end{array}$} & \multicolumn{3}{|c|}{$\begin{array}{l}\text { Number of cells invaded by } \\
\text { infection hyphae }\end{array}$} \\
\hline & & & $24^{a)}$ & 48 & 72 \\
\hline I & $\begin{array}{l}\text { 1-(3,4-dichlorophenyl)- } \\
\text { 2-acetylhydrazine }\end{array}$ & 1000 & 1. 27 & 1.73 & 2. 33 \\
\hline \multirow[t]{4}{*}{ II } & $\begin{array}{l}\text { 1-(4-chloropheny })-2- \\
\text { acetylhydrazine }\end{array}$ & 1000 & 1. 27 & 2.00 & 2. 17 \\
\hline & PMI & $20^{b)}$ & 1. 27 & 1.75 & 3. 09 \\
\hline & Blasticidin S & 20 & 1. 27 & 1.63 & 2.00 \\
\hline & Check & - & 1. 27 & 2.62 & 6.60 \\
\hline
\end{tabular}

a) Hours after inoculation. Leaf sheath tissues were dipped 10 minutes in each chemical solution 24 hours after inoculation.

b) Concentration as mercury.

1-(2-chlorophenyl)-2-acetylhydrazine

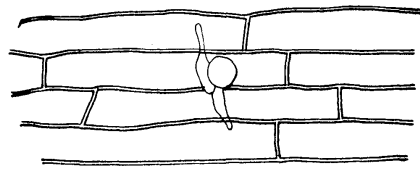

1-(3,4-dichloropheny1)-2-acetylhydrazine

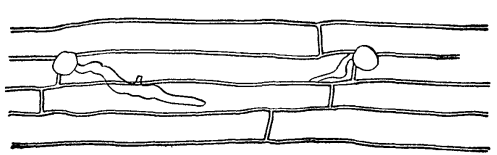

$\mathrm{BcS}$

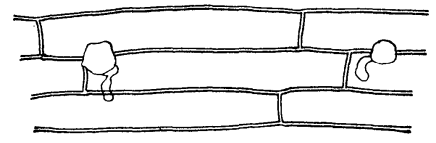

PMI

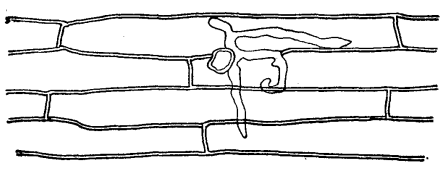

Control

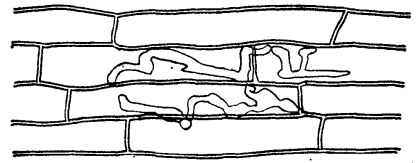

Fig. 4 Effect of $\beta$-acetylchlorophenylhydrazines, $\mathrm{BcS}$ and PMI on mycelial development in leaf sheath of rice seedling 48 hours after inoculation (24 hours after chemical treatment).
経過で, 組織内部の菌系に対してかなり強い作用を示 し, さらに 24 時間後では PMI よりもその阻害が強 く現われ， BcS の効果に潘ぼ匹敵した。経時変化か らみると $\mathrm{BcS}$ にくらべてやや遅効的であるように思 われる。

以上の結果から $\beta$ アアシルクロロフェニルヒドラジ ン誘導体は，予防散布の場合でも葉上での分生胞子発 芽, 付着器形成などを強く抑えないが，組織内に侵入 した菌糸に対し強い阻害作用を示すと思われる。さき の in vitro の結果からも，これらの誘導体は菌糸に 対してもっとも強い殺菌力を示し，in vivo の結果と の関連が認められた。また前報引で，これらの化合物 を散布した場合，褐点型病斑で止る場合が多く観察さ れたが，この現象は以上に述べた侵入後の菌糸に対し てやや強く作用する特性からよく説明できると思われ る。

\section{摘 要}

ß-アシルクロル置換フェニルヒドラジン誘導体の 中で特に高いいもち病防除効果を示した 1-(3,4-dichlorophenyl)-2-acetylhydrazine (I) および 1-(4chlorophenyl)-2-acetylhydrazine (II) につきin vitro およびイネ葉上，組織内に护けるいるち病菌分 生胞子発芽和よび菌糸生育に対する阻害作用について 検討した。

I は in vitroに拈いて胞子発芽, 菌系生育に対し, おのおの 125 および $175 \mathrm{ppm}$ 以上で強い静菌作用 を示した。一方殺菌的には胞子より菌糸に対し強い阻 害を示した。

イネ葉上に拈いては $1000 \mathrm{ppm}$ の薬液を散布し2 
日後に接種した場合, I および II は胞子発芽, 付着 器形成に対して十分な阻害を示さなかった。ところが イネ葉䩗組織内に扣いてはともに侵入菌系の伸長を強 く抑制し,ブラストサイジンS とほぼ同程度の作用で あった。

以上の結果から $\beta$-フシルフェニルヒドラジン誘導 体は予防あるいは治療散布のいずれの場合でも, 組織 内侵入菌䊽対してもっとも強く作用すると考兄られ る。

\section{引用 文 献}

1. Matsuura, K. (1965). Ann. Rept. Takeda
Res. Lab. 24: 266-272.

2. 西山市三 (1961). 細胞遗伝学研究法 (西山市三 編). 東京. p p. 48, 180.

3. 角名郁郎 - 松浦一穂 - 北村吉霸・碓井義郎 (1967). 日植病報 $33: 132-137$.

4. 湭元清透 (1958). 微生物学拉よび植物病理学実 験法. 東京. pp. 198-199.

5. Yanagita, T. and Yamagishi, S. (1958). Appl. Microbiol. 6: 375-381. 